Journal of Social Sciences 2 (4): 100-103, 2006

ISSN 1549-3652

(C) 2006 Science Publications

\title{
A Price Survey Comparison of Alcoholic Beverages with the Five Basic Food Groups in Paraiba, Brazil
}

\author{
${ }^{1}$ Charles I. Abramson, ${ }^{1}$ Waylon Howard, ${ }^{1}$ Mia Zolna, ${ }^{2}$ Shakuntla Nain, ${ }^{3}$ Italo S. Aquino, ${ }^{4}$ Herbert Rocha \\ ${ }^{5}$ Zeyna Moraes and ${ }^{1}$ Melanie M. Page \\ ${ }^{1}$ Oklahoma State University, Department of Psychology, 215 N. Murray, Stillwater, OK 74078, U.S.A. \\ ${ }^{2}$ Universidade Federal de Campina Grande, Departamento de Educação \\ Campina Grande 58109-970, Paraiba Brazil \\ ${ }^{3}$ Universidade Federal da Paraiba, Departamento de Entomologia, Bananeiras, 58220-000, Paraiba Brazil \\ ${ }^{4}$ Universidade Federal de Campina Grande, Departamento de Engenharia Agrícola \\ Campina Grande 58109-970, Paraiba Brazil. \\ ${ }^{5}$ Pet Sci., LLC, Stillwater, OK 74075, U.S.A
}

\begin{abstract}
The study of alcohol abuse is relatively new in Brazil. Government estimates suggest that $11.2 \%$ of the Brazilian population is alcohol dependent. Problems associated with alcohol dependence include domestic violence, increased risk of traffic accidents, poor self-esteem and weak academic performance. A factor known to correlate with alcohol abuse in 12-17 year olds is to have the money necessary to purchase alcoholic beverages. No data is available, however, on the price of alcoholic beverages. The objective of the present study was to provide data on price and to compare the price of alcoholic beverages to basic food items in the Brazilian diet. We also had interest in studying a population in the northeast region of Brazil. This region is the poorest in Brazil, has the highest percentage of alcohol dependency and is seldom the focus of research on dependency. We report that the prices of many alcoholic beverages are less than the price of basic food items. Prices of alcoholic beverages including beer, wine and spirits were compared to the prices of select food items as represented in the Food Pyramid. Food items were selected from the categories of Grain, Dairy, Fruit, Meat and Vegetable. Data was gathered from 32 supermarkets in 8 cities in the northeast state of Paraiba. The price of alcohol is generally less expensive than most basic food group items, especially brands of cachaça (a spirit distilled from sugar cane) and beer. Data on price should be considered in any alcohol dependency program in Brazil.
\end{abstract}

Key words: Brazil, alcoholism, nutrition

\section{INTRODUCTION}

The study of ethanol consumption and the social problems correlated with excess, is relatively recent in Brazil. An epidemiological survey of ethanol use in Brazil for 1987, 1989, 1993 and 1997 by the Brazilian Information Center on Psychotropic Drugs showed significant increases in the percentages of interviewees reporting heavy use of alcoholic beverages in 7 of 10 capitol cities surveyed ${ }^{[1]}$. Heavy use was defined as drinking 28 or more times in a one month period and the most recent data obtained in 1997 estimated that 20,608.00 (11.2\%) of Brazilians are alcohol dependent. Some researchers consider this percentage to be even higher than official government projections. Alcohol dependence in Brazil contributes to spousal and child abuse, low self-esteem, poor academic performance, traffic accidents and behavioral problems as it does in the United States ${ }^{[2-4]}$.
A factor known to correlate with alcohol abuse in Brazilian elementary and high school students is having the money necessary to purchase alcoholic beverages ${ }^{[4]}$. In reviewing the few studies of alcohol dependency in Brazil, we were struck by the lack of data on the price of alcoholic beverages. The United States authors of this paper expressed surprise when informal observations suggested low prices and easy accessibility of alcoholic beverages; the Brazilian authors did not express such surprise. The price of a liter of cachaça (a type of spirit distilled from sugarcane), for example, can be found for 90 centavos (approximately 40 cents). Moreover, various spirits such as whiskey and rum can be sampled freely in some of the larger chain supermarkets such as Bompreço (translated as "Good Price"). Bompreço was recently bought by WalMart and now is officially known as "WalMart Brasil."

Corresponding Author:

C. I. Abramson, Laboratory of Comparative Psychology and Behavioral Biology, Departments of Psychology and Zoology, 215 N. Murray, Stillwater, OK 74078, Tel: (405) 744-7492, Fax: (405) 744-8067 
This study provides data on the price of alcoholic beverages compared to food. Our rationale for comparing the price of alcoholic beverages to food prices is an obvious one: dependent and abusive individuals must often choose between purchasing alcoholic beverages or food. Alcohol is not considered to be a part of a well-balanced diet and is not recommended for regular consumption because of its low nutrient and high caloric nature. Our results indicate that the price of many alcoholic beverages is less expensive than most basic food group items, especially brands of beer and cachaça.

\section{MATERIALS AND METHODS}

Selection of food items: The food items chosen for this study were based on availability, recommendations of Brazilian colleagues on foods typically consumed and on dietary guidelines found in the Food Guide Pyramid established by United States Department of Agriculture and the United States Department of Health and Human Services. Whenever a particular brand of food was not available in a particular store, a similar substitute was selected. These items included (Grain Group): bread, rice, beans, (Dairy Group) milk, powdered milk, cheese, (Fruit Group) apples, oranges, bananas, pears, tomatoes, (Meat Group), eggs, beef, ham, pork, sausage, turkey, fish, chicken, (Vegetable Group) roots, Chuchu (a type of tropical vegetable), carrots, potatoes. We would like to note that apples and pears are available seasonally and are considered expensive by northeast Brazilian standards.

Selection of alcoholic beverages: The alcoholic beverages selected for use in this study included: Cachaça: (Pitu $965 \mathrm{~mL}, 40 \%$ alcohol, Ypioca $960 \mathrm{~mL}$, $39 \%$ alcohol, Pirassununga, $965 \mathrm{~mL}$, bottle and $350 \mathrm{~mL}$ can, 39\% alcohol, Rainha $620 \mathrm{~mL}, 50 \%$ alcohol); Whiskey: (Teacher's 1,000 mL, 40\% alcohol, Drury's $1,000 \mathrm{~mL}, 38 \%$ alcohol, Old Eight 1,000 mL, 39\% alcohol); Rum: (Montilla Carta Branca, $1000 \mathrm{~mL}, 38 \%$ alcohol, Montilla Cristal, $1000 \mathrm{~mL}, 38 \%$ alcohol, Merino $1000 \mathrm{~mL}, 38 \%$ alcohol); Beer: (Kaiser $350 \mathrm{~mL}$, $4.6 \%$ alcohol, Antartica $350 \mathrm{~mL}, 5 \%$ alcohol and Brahma Chopp $350 \mathrm{~mL}, 5 \%$ alcohol) and wine: (Chapinha, Red Dry Wine, $750 \mathrm{~mL}, 10.7 \%$ alcohol, Chalise, Red Dry Wine, $750 \mathrm{~mL}, 11.5 \%$ alcohol and Sangue de Boi, Red Dry Wine, $750 \mathrm{~mL}, 10.7 \%$ alcohol). The beverages were selected based primarily on availability and popularity.

Selection of markets: We gathered data for this study from a wide variety of markets. Some markets were very large with an enormous sales volume. Thus, these stores often carry numerous brands of the same type of item. Other markets were very small and have an extremely low volume of sales by comparison to the larger stores. These markets often carried only one brand of the basic food types, such as rice for example. Only one supermarket chain (Bompreço) was reviewed in this study and is considered the largest chain in Paraiba.

The most popular alcoholic beverage in Brazil is beer (cerveja) with an average consumption per individual of 54 liters per capita/year, cachaça 12 liters per capita/year and wine with 1.8 liters per capita/year ${ }^{[1]}$. Prices were obtained during July 2003 and included 32 different stores in 8 different cities: Campina Grande, (population 376,132 - second largest city in Paraiba) Lagoa Seca (population 25,717), São Sebastião de Lagoa de Roça (population 10,798), Esperança (population 28,524), Remigio $(14,737)$, Arara $(12,558)$, Solânea $(31,957)$ and Bananeiras $(20,966)$. The cities were selected because they formed essentially a straight line from Campina Grande to Bananeiras.

The cities were from the northeast state of Paraiba. Paraiba was selected for several reasons. First it is considered one of the poorest states of the 26 states in Brazil. Paraiba contains 12 micro-regions and is part of the northeast "sertão" which encompasses about $10 \%$ of Brazil and is subject to long periods of drought and subsequent unemployment and extreme poverty ${ }^{[5]}$. The monthly salary of the majority of the Paraiba population is 350 reais/month which converts to approximately $\$ 152.17$ at current exchange rates (2.3 dollars/real). Second, with the exception of capitol cities in the northeast (Fortaleza, Recife, Salvador) northeastern cities are seldom studied. Data are typically gathered from such well known Brazilian cities as São Paulo, Rio de Janeiro, Brasilia and Curitiba. We found this surprising because compared to other regions in Brazil (center west, southwest, south), the northeast has significantly more lifetime alcohol dependent individuals ( $16.9 \%$ of population) and more dependent adolescents (9.3\% of population) than any other region. These numbers increase substantially when the north region is considered (16.3 and $9.2 \%$ respectively $)^{[1]}$.

\section{RESULTS}

The price of alcoholic beverages is generally less expensive than most basic food group items, especially brands of cachaça. A $965 \mathrm{~mL}$ bottle of Pitu, for example, is less expensive than a kilogram of bread, apples, cheese, milk, beef, chicken, eggs, or fish. Interestingly, the price of a package of 30 eggs is more expensive than a $965 \mathrm{~mL}$ bottle of Pitu and a $965 \mathrm{~mL}$ bottle of Pirassununga combined. Similar results derive from powdered milk, cheese, beef and fish.

Descriptive analyses: Cachaça: Cachaça mainly comes in two sizes $-965 \mathrm{~mL}$ or $350 \mathrm{~mL}$. The average price for a $965 \mathrm{~mL}$ bottle was 3.12 Reais (range $1.69-8.40$ Reais). The average price for a $350 \mathrm{~mL}$ can was 1.54 Reais (range 1.00 to 2.68 Reais). To investigate the 
large range for the bottles, we examined price further by brand. The average price of Pitu was R2.59; Pirassununga was R2.65; Ypioca was R3.81; Marata was R2.07; Caranguejo was R2.17; São Francisco was R4.49; Especial was R7.98; Serra Preta was R8.40. Rainha was not included in the above calculations as it came in a non-standard size bottle of $620 \mathrm{~mL}$. Its average price was R8.04 (range 7.50 to 8.80 Reais); $84 \%$ of cans were Pirassununga and $50 \%$ of bottles were Pitu or Pirassununga.

Whiskey: Whiskey was always sold in a 1000 $\mathrm{mL}$ bottle and the average cost was R21.20 (range 7.48 to 25.49 Reais).

Beer: Beer was always sold in a $350 \mathrm{~mL}$ can and cost an average of R1.02 (range .79 to 1.20 Reais).

Wine: Wine was always sold in $750 \mathrm{~mL}$ bottles and cost an average of R4.33 (range 3.22 to 7.00 Reais).

Rum: Rum was always sold in $1000 \mathrm{~mL}$ bottles and cost an average of R8.05 (range 6.50 to 10.90 Reais).

Soda and Water: Soda (Refrigerante) and water were also sold in $350 \mathrm{~mL}$ and cost an average of R.95 (range .72 to 1.50 Reais) and R1.05 (range .95 to 1.25 Reais), respectively.

Milk: Liquid milk is sold in $1000 \mathrm{~mL}$ containers. The average price was R1.92 (range 1.29 to 5.81 Reais). Powdered milk was an average of R4.97 a container (range 4.69 to 5.40 Reais).

Cheese: Cheese was an average of $\mathrm{R} 10.47 / \mathrm{kg}$ (range 5.25 to 22.24 Reais)

Vegetables: The vegetables surveyed in this study were carrots, potatoes and chu-chu. Average price was $\mathrm{R} 1.38 / \mathrm{kg}$ (range .59 to 2.53 Reais).

Fruit: The fruits in this study included apples, pears, oranges and bananas. The average price was $\mathrm{R} 2.38 / \mathrm{kg}$ (range .41 to 5.78 Reais).

Bread: A loaf of bread which weighs $1 \mathrm{~kg}$ was R3.39 (range 1.79 to 4.59 Reais).

Rice: The average price for rice was $1.96 / \mathrm{kg}$ (range 1.39 to 2.99 Reais).

Meat: The meats included in this study were beef, pork and chicken. The average price was $\mathrm{R} 6.40 / \mathrm{kg}$ (range 1.60 to 14.99 Reais).

Fish: $\quad$ Fish was an average of R12.15/kg (range 1.5 to 47.46 Reais).

Beans: $\quad$ Beans were an average of R2.19/kg (range 2 to 3 Reais).
Campina Grande vs. stores in other cities: There were eight stores in Campina Grande, which is the largest city surveyed. There were 24 stores in other locations. All of the stores surveyed in Campina Grande, except for the outdoor market, carried milk, rice, whiskey, rum and multiple brands of cachaça. They all had vegetables and meat and only one did not have fruit. Two stores did not carry fish, three did not have cheese and four did not have bread or beer. Twenty-one stores carried cachaça and only 4 did not have multiple types of alcohol (usually whiskey and rum). Thirteen stores had beer and 8 had wine. Seventeen of the stores did not carry fruits and 16 did not carry vegetables. Sixteen stores did not carry bread, only three did not carry rice, five did not carry beans, but 11 had no meat and 21 had no fish. All of the stores had either milk or cheese.

Differences between prices in Campina Grande and the other stores were tested through independent sample t-tests. There were no significant difference between Campina Grande and the other stores on the price of cachaça, whiskey, beer, fruit, bread, fish, or rum (all p's $>$.05). There were significant differences between Campina Grande and the other stores on the price of milk, vegetables, cheese, rice and meat (Table 1). It can be seen that the prices were almost always higher in Campina Grande.

\begin{tabular}{lccc} 
Table 1: & Price comparison & & \\
\hline Item & $\begin{array}{l}\text { Campina } \\
\text { Grande price }\end{array}$ & $\begin{array}{l}\text { Other stores } \\
\text { price }\end{array}$ & $\begin{array}{l}\text { t value } \\
(\mathrm{df})\end{array}$ \\
\hline Milk & 1.49 & 1.75 & $-6.10(30)^{* * *}$ \\
Vegetables & 1.59 & 1.10 & $4.02(48)^{* * *}$ \\
Cheese & 13.63 & 8.83 & $4.54(48)^{* * *}$ \\
Rice & 2.23 & 1.90 & $2.41(39)^{*}$ \\
Meat & 7.20 & 5.50 & $2.16(55)^{*}$ \\
\hline Note: ${ }^{*}=\mathrm{p}<.05 ; * * *=\mathrm{p}<.001$. & &
\end{tabular}

Alcohol vs. other food items: In order to determine if alcohol was priced higher than food staples, we compared the average price of each type of alcohol (cachaça, whiskey, rum, beer and wine) to the mean of several of the food classes (milk, cheese, meat, fish, fruit, vegetables and rice). These analyses were one sample t-tests in which the test value was the price of the other food items. Results showed that in every comparison but one, the alcohol was significantly different than the other food items (wine and powdered milk were not significantly different; all other $p$ 's $<.001)$. Cachaça was more than milk, rice, fruit and vegetables and less than powdered milk, cheese, meat and fish. These relationships hold for bottles and cans and for even the least expensive brand of cachaça, except that the price of the least expensive brand was not significantly different than the price of vegetables. Rum was more expensive than everything but cheese and fish. Wine was more expensive than everything except cheese, meat and fish. Beer was less expensive than everything and whiskey was more expensive than everything. We would like to note that the less 
expensive beverage of any group (beer, cachaça, etc) will often be less than most food items.

\section{DISCUSSION}

The results of our survey show that for many types of alcoholic beverages, the price is less expensive than many basic food items. This is especially the case for beer and cachaça. Our data might actually under report differences between the price of alcoholic beverages and the prices of basic food items because of the large presence of illegal or "home breweries" in Brazil. Data obtained from the Brazilian Association of Beverages estimated that approximately $50 \%$ of spirits were produced illegally in 1984 - the latest available data ${ }^{[6]}$. The current percentage is unknown ${ }^{[1]}$. As we noted earlier, a liter of cachaça can easily be found for approximately 40 cents (90 centavos).

Although beer is the most popular alcoholic beverage in Brazil as measured by sales, cachaça deserves special mention because of its role in Brazilian society, especially in the north and northeast. In 1922, for example, during the Brazilian "Modern Art Week" cachaça was designated as being a genuine Brazilian product alongside the samba and feijoada. Cachaça is a sub-product derived from sugar cane and has been part of the Brazilian economy since the $16^{\text {th }}$ century. It was originally offered to slaves to relieve stress associated with sugarcane harvest. As the drink became popular, distilleries known as "Engenhos" were created to produce it and small towns would develop around an Engenho to house its workers. As a result, many local brands of cachaça are available at very inexpensive prices. Cachaça was originally known as a "poor mans" drink and one who became intoxicated on cachaça was known, and is still known, by the derogatory expression "cachaceiro." Recently, however, cachaça has begun to be exported and the stigma associated with drinking cachaça has lessened.

We believe that our data should be considered in any alcohol dependency program in Brazil. Dependent and abusive individuals, especially those making the minimum salary, are faced with a choice to purchase food or alcohol. The fact that the price of such beverages is well within the reach of all but the youngest Brazilian citizens makes this choice a simple one. Some treatment providers in the United States might suggest that dependency can be reduced by increasing the sales tax on alcoholic beverages. The amount of sales tax is already high. Cachaça, for example is taxed $83 \%$, beer $56 \%$ and wine $45 \%{ }^{[7]}$. Increasing taxes further may only encourage Brazilians to purchase alcohol at illegal distilleries.

\section{ACKNOWLEDGEMENTS}

This work was supported in part by a Research Experience for Undergraduates grant from the National Science Foundation (SES-024414) to Melanie C. Page and Charles I. Abramson. Further financial support was provided by a visiting professor grant to Charles I. Abramson from the Universidade Estadual da Paraíba.

\section{REFERENCES}

1. Galduróz, J.C.F. and R. Caetano, 2004. Epidemiology of alcohol use in Brazil. Rev. Bras. Psiquiatr., 26: 3-6.

2. Zilberman, M.L. and S.B. Blume, 2005. Domestic violence, alcohol and substance abuse. Rev. Bras. Psiquiatr., 27: 51-55.

3. Zanoti-Jeronymo, D.V. and A.M.P. Carvalho, 2005. Self-concept, academic performance and behavioral evaluation of the children of alcoholic parents. Rev. Bras. Psiquiatr., 27: 233-236.

4. Soldera, M., P. Dalgalarrondo, H.R.C. Filho and C.A.M. Silva, 2004. Heavy alcohol use among elementary and high-school students in downtown and outskirts of Campinas City - São Paulo: prevalence and related factors. Rev. Bras. Psiquiatr., 26: 74-79.

5. Weil, T., 1975. Area Handbook for Brazil. American University, Washington, DC.

6. Masur, J. and M.R. Jorge, 1986. Dados relacionados a bebidas alcoólicas e alcoolismo no Brasil: uma revisão. (The relationship between drinking alcohol and alcoholism in Brasil: A review). Revista ABP-APAL., 8: 157-165.

7. Instituto Brasileiro de Planejamento Tributário, http://www.ibpt.com.br. 